\section{INFLUENCE OF ENVIRONMENTAL FACTORS ON THE BREEDING SUCCESS OF THE GREY SHRIKE LANIUS EXCUBITOR IN THE ARID ZONE OF RAJASTHAN, INDIA}

\author{
A.N. Sharma ${ }^{1}$ and K.C. Soni ${ }^{2}$ \\ 1,2 P.G. Department of Zoology, Govt. Lohia P.G.College, Churu, \\ Rajasthan 331001, India \\ Email: ${ }^{2}$ kcsibis@yahoo.com (corresponding author)
}

Breeding biology and ecology of the Grey Shrike Lanius excubitor has been studied in Belarus and Ukraine (Gorban, 2000; Ivanovsky \& Kuzmenkov, 2000). The Grey Shrike has been studied little for its habit and habitat in India (Ali, 1961; Ali \& Ripley, 1983). An attempt to study the influences of environmental factors viz., habitat destruction, rain fall and sand storms during breeding season on the Grey Shrike (Lanius excubitor).

Materials and methods: Nests of Grey Shrike were observed for one year (2005) during the breeding months (February to August) at one sampling site $\left(10 \mathrm{~km}^{2}\right)$ in the Khasoli agricultural fields, Churu $\left(29^{\circ} \mathrm{N}-75^{\circ} \mathrm{E}\right.$, rainfall $325 \mathrm{~mm}$, altitude $286 \mathrm{~m}$ ). These nests were observed for 90 days for $3 \mathrm{hr}$ (1500 to $1800 \mathrm{hr}$ ) from the period of nest site selection till the chicks fledged. Observations were made from the hide in the close vicinity of the nests to record the clutch size, hatching and fledgling success per nest. The average number of eggs laid, hatched and young fledged was calculated. The number of nests built on trees (Acacia sp.) was 12 as compared to 18 nests in undisturbed habitat in $10 \mathrm{~km}^{2}$ of the field. Out of 12 nests, six were built below the $2.5 \mathrm{~m}$ height from the ground. The number of nests built was restricted to $12 \mathrm{in} 10 \mathrm{~km}^{2}$ of the field because of limited perching sites and nests due to habitat loss. The loss of habitat resulted from cultivation of land and deforestation.

Results and Discussion: The total number of eggs in all the 12 nests was 35 . The average clutch size, number of young hatched and young fledged were $2.9 \pm 0.04,2.10 \pm 0.21$ and $0.5 \pm 0.01$, respectively. The hatching success and fledgling success was low in disturbed habitat as compared to undisturbed habitat where the average clutch size, number of

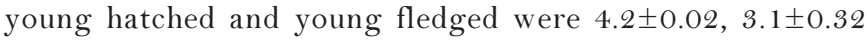
and $2.10 \pm 0.2$.

The rains and storms not only destroyed nests of the shrikes but resulted in a decrease in prey taxa, requiring more hunting effort and affecting nestling growth and survivorship through exposition to bad weather (Hornman et al., 1998). The survival and growth of the population may be increased by habitat improvement. Optimal Grey Shrike habitat includes: (i) elevated perches to easily look for terrestrial prey; (ii) open rough ground with low grassland vegetation for hunting together with tall grasses to increase insect availability as prey; (iii) thorny bushes for nesting; (iv) keeping thorny bushes up to $2.5 \mathrm{~m}$ height where damage caused by storms is minimum. Similar recommendations have been made for Red-backed Shrike (Baker et al., 1989; Van \& Vandekerkhove, 1992; Yosef
\& Grubb, 1993)

We recommend that conservation action which may minimize the effects of bad weather conditions by (i) preserving fences and developing large perching sites to regulate the breeding density; (ii) improving the diversity and vigour of prey; (iii) improving the quality of shrubs which may discourage nest height above $2.5 \mathrm{~m}$ which is more affected by storms.

\section{REFERENCES}

Ali, S. (1961). The Book of Indian Birds. Bombay Natural History Society. Mumbai, $158 \mathrm{pp}$

Ali, S. \& S.D. Ripley (1983). Pictorial Guide to the Birds of the Indian Subcontinent. Oxford University Press, Delhi, 177pp.

Bakker, J.P., J. De leeuw \& S.E. Van Wieren (1989). Micro-patterns in grass land vegetation created and sustained by sheep grazing. Vegetation 55: $153-161$

Gorban, I. (2000). Wintering behaviour of the Great Grey Shrike (Lanius excubitor) in the western Ukraine. Ring 22(1): 45-50.

Hornman, M., M. Nijssen, M. Geertsma, J. Kuper \& H. Esselink (1998). Temporal effects on diet composition in nestling Red backed Shrike (Lanius collurio) in bargerveen, the Netherlands. IBCE Tech Publication 7: 83-87.

Ivanovsky, V.V. \& J. Kuzmenkov (2000). Breeding biology and ecology of the Great Grey Shrike (Lanius excubitor) in northern Belarus. Ring 22(1):181-183.

Van, N. \& K. Vandekerkhove (1992). Caracteristiques et typologie des territories de la lie-grieche ecorchear Lanius colluria en Lorrainebelge. Aves 29:137-154.

Yosef, R. \& T.C. Grubb (1993). Effect of vegetation height on hunting behaviour and diet of Loggerhead Shrikes. Condor 95: 127-131.

\section{ACKNoWledgement}

We are grateful to AZARI (Arid Zone Avian Research Institute), Churu for providing facilities.

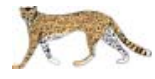

Manuscript 1555; ( ) ZOO; Date of publication 21 May 2007 Received 08 April 2006; Revised received 29 March 2007; Finally accepted 27 April 2007 